\title{
INTERPRETING THE TARIFF-GROWTH CORRELATION OF THE LATE NINETEENTH CENTURY
}

\author{
Douglas A. Irwin \\ Working Paper 8739 \\ http://www.nber.org/papers/w8739 \\ NATIONAL BUREAU OF ECONOMIC RESEARCH \\ 1050 Massachusetts Avenue \\ Cambridge, MA 02138 \\ January 2002
}

The views expressed herein are those of the author and not necessarily those of the National Bureau of Economic Research.

(C) 2002 by Douglas A. Irwin. All rights reserved. Short sections of text, not to exceed two paragraphs, may be quoted without explicit permission provided that full credit, including $\mathbb{C}$ notice, is given to the source. 
Interpreting the Tariff-Growth Correlation of the Late Nineteenth Century

Douglas A. Irwin

NBER Working Paper No. 8739

January 2002

JEL No. F1, N7

\begin{abstract}
$\underline{\text { ABSTRACT }}$
Recent research has documented a positive relationship between tariffs and growth in the late nineteenth century. Such a correlation does not establish a causal relationship between tariffs and growth, but it is tempting to view the correlation as constituting evidence that protectionist or inward-oriented trade strategies were successful during this period. This paper argues that such a conclusion is unwarranted and that the tariff-growth correlation should be interpreted with care. First, several individual country experiences in the late nineteenth century are not consistent with the view that import substitution promoted growth. For example, the two most rapidly expanding, high tariff countries of the period - Argentina and Canada - grew because capital imports helped stimulate export-led growth in agricultural staples products, not because of protectionist trade policies. Second, most land-abundant countries (such as Argentina and Canada) imposed high tariffs to raise government revenue, and revenue tariffs have a different structure than protective tariffs. The fact that labor-scarce, land-abundant countries had a high potential for growth and also tended to impose high revenue-generating tariffs confounds the inference that high tariffs were responsible for their strong economic performance during this period.
\end{abstract}

Douglas A. Irwin

Department of Economics

Dartmouth College

Hanover, NH 03755

and NBER

douglas.irwin@dartmouth.edu 


\section{Interpreting the Tariff-Growth Correlation of the Late Nineteenth Century}

Immediately following World War II, many economists believed that a trade policy based on import substitution would best promote economic development. Subsequent experience instead revealed the costs of protectionism (Krueger 1997). In the late nineteenth century as well, many political economists (such as Friedrich List) advocated import tariffs to promote the growth of domestic manufacturing in countries that were behind the industrial leader, then the United Kingdom. But unlike the recent period, the late nineteenth century experience is often interpreted as confirming the wisdom of import substitution. Writing in the Cambridge Economic History of Europe, Bairoch (1989, p. 69) concluded that "protectionism [equaled] economic growth and expansion of trade; liberalism [equaled] stagnation in both" in the late nineteenth century. Recent work by O'Rourke (2000) and Clemens and Williamson (2001) has strengthened this impression by finding a positive correlation between import tariffs and economic growth across countries from 1875 to 1914.

Such a correlation does not establish a causal relationship between tariffs and growth, but it is tempting to view the correlation as constituting evidence that protectionist or inwardoriented trade strategies were successful during this period. This paper argues that such a conclusion is unwarranted and that the tariff-growth correlation should be interpreted with great care. First, several individual country experiences in the late nineteenth century are not consistent with the view that import substitution promoted growth. For example, the two most rapidly expanding, high tariff countries of the period - Argentina and Canada - grew because capital imports helped stimulate export-led growth in agricultural staples products, not because of protectionist trade policies. 
Second, most land-abundant countries (such as Argentina and Canada) imposed high tariffs to raise government revenue, and revenue tariffs have a different structure than protective tariffs. The fact that labor-scarce, land-abundant countries had a high potential for growth and also tended to impose high revenue-generating tariffs confounds the inference that high tariffs were responsible for their strong economic performance during this period.

\section{The Tariffs-Growth Relationship: Country Evidence}

Figures 1 presents the unconditional relationship between the average tariff in 1870 and the average annual growth in real per capita GDP from 1870 to 1913 for 17 high-income "core" countries. ${ }^{1}$ Average tariffs, calculated by dividing customs revenue by the value of imports, are the most frequently used indicator of trade policy for this period. ${ }^{2}$ For these core countries, the correlation between tariffs and growth is 0.68 , but a causal interpretation of this correlation is questionable.

First, the correlation is driven by several key outliers: Argentina, Canada, and the United States stand out as high tariff, high growth countries. Without these three countries, the correlation falls to 0.08 . These labor-scarce, land-abundant New World economies had the potential for rapid growth that other European countries did not possess. For example, it is

1 The core includes most of Western Europe as well as Argentina, Australia, Canada, New Zealand, and the United States. The eleven low-income countries of the periphery are Greece, Spain, Portugal, Russia, Japan, China, India, Indonesia, Thailand, Brazil, and Mexico. GDP data are from Maddison (2001).

2 Other trade policy instruments, such as import quotas, voluntary export restraints, and antidumping duties, were rarely employed during this period. But this tariff measure is a crude indicator of trade policy because it provides no information on the structure of protection across industries or sectors. 
doubtful that the Netherlands could have achieved growth rates equal to those of the New World economies simply by imposing a higher tariff.

Second, the core sample may be too limited. Figure 2 adds eleven low-income periphery countries to the sample. The inclusion of countries such as Portugal and Brazil, which had high tariffs but poor growth performance, reduces the tariff-growth correlation from 0.68 to 0.20 (or from 0.08 to -0.09 if Argentina, Canada, and the United States are excluded).

Third, a descriptive analysis of the high tariff, high growth outliers suggests that tariffs did not play a major role in their economic development in the late nineteenth century. For example, Argentina achieved the highest recorded rate of growth in per capita income during this period and had very high average tariffs. But its trade policy was not designed to foster inwardoriented development and its growth was not based on industrialization achieved through import substitution. Argentina grew rapidly because it experienced an investment boom that led to an export boom in staple products. Argentina received massive foreign investment (particularly from Britain) in the 1880s that resulted in the construction of thousands of kilometers of railroad track and other infrastructure-related public works. This literally paved the way for an enormous expansion in exports, particularly wheat and livestock. As Cortés Conde (1993, p.75) explains, the "growth which changed Argentina was based on the exploitation of staples: agricultural and cattle products which found an outlet in international markets."

Argentina's tariff code was not designed to promote industrialization based on import substitution and "industrial growth did not stem from protectionist tariffs" (Cortés Conde 1993, 
p. 68). ${ }^{3}$ As a by-product of the expansion of agricultural exports, complementary activities both in manufacturing (food processing) and in services (transportation and construction) arose and absorbed an increasing share of the labor force. Capital investments were direct toward activities that would develop, facilitate, and service the agricultural exports and were not undertaken to produce goods domestically in replace of imports. Thus, "manufacturing growth came mainly from export expansion plus growth of the domestic market, with import substitution playing a minor role" (Reynolds 1985, p. 88). ${ }^{4}$

Canada was another high tariff country that grew rapidly from 1896 to 1913 , but this growth was not the result of import substitution or an inward-oriented development strategy. Like Argentina, Canada experienced "a classic investment boom, a major part of it related directly or indirectly to the settlement of the west. . . that the settlement of the west was based on the expectation, in the minds of the settlers, of there being a viable [international] market for wheat is beyond doubt" (Urquhart 1986, pp. 35-36). Substantial investment in railroads (such as the Canadian Pacific Railroad extending into the prairies) in the 1880s made possible an export boom in its staple products, particularly wheat and flour. Industrialization was not critical to its growth; indeed, during the period of its most rapid growth from 1891 to 1911, the share of the

3 Solberg (1987, p. 106) notes that "Although some Argentine industries did enjoy marked tariff protection, no government during the 1880-1930 period attempted a consistent protectionist policy to spur industrial growth through massive import substitution."

${ }^{4}$ Reynolds (1988, p. 88) further observes that "manufacturing output [in Argentina] during this period grew only a little faster than GDP and was linked rather closely with export expansion. Meat-packing firms, flour mills, and wool-washing establishments shipped a large part of their output abroad. Railroad construction and repair, other export-oriented infrastructure facilities, and housing and urban facilities for immigrants also provided a stimulus to manufacturing." 
labor force in Canadian industry (manufacturing and construction) was unchanged (Urguhart 1993, pp. 24, 305).

Thus, two high tariff countries did grow rapidly, but export-led growth is a better description of their development process than import substitution. What about the link between tariffs and growth in other countries? In the United States, high tariffs on manufactured goods originally imposed during the Civil War were kept in place after the war, but the United States overtook Britain in terms of per capita income primarily by improving its productivity in the service sector, not in manufacturing (Broadberry 1998, Irwin 2001). In Western Europe, Figure 1 suggests that the variation in tariff levels as well as the differences in growth performance were relatively small, making it difficult to draw firm conclusions.

Australia is an interesting case to consider. At first glance, Australia has characteristics similar to Argentina and Canada - an agricultural exporter with high tariffs, abundant land, and scarce labor. But unlike the others, Australia grew slowly during this period, perhaps due to the fact that its share of employment in agriculture was already low by 1870 and therefore the possibility of growth through structural change was limited. Australia is also intriguing because each of the several colonies there pursued independent trade policies before Federation in 1901. The two largest colonies, New South Wales and Victoria, adopted different tariff policies: New South Wales eschewed tariffs and embraced free trade, while Victoria imposed protectionist tariffs to promote manufacturing. The outcome of this experiment suggests that tariffs were not decisive: as measured by the level or the growth of per capita GDP, economic performance in the colonies was not all that different (Haig 2001).

Some countries did pursue import substitution policies during this period. In Russia, for 
example, "this process of import substitution and export promotion was actively fostered by the government through tariff protection, government orders, location of railways and the railway rate structure, and export premiums" and "was particularly dramatic for cotton fibre, copper, steel, cloth and many types of machinery," according to Dohan (1991, p. 215). Russia grew rapidly after the $1880 \mathrm{~s}$, but doubts remain about the degree to which the tariff protection helped manufacturing overall. ${ }^{5}$ Mexico also imposed high tariffs and brought about "substantial import substitution, particularly in textiles, clothing, processed foods and beverages, tobacco, cement, and other building materials" (Reynolds 1985, p. 100). Whether restrictive trade policies were responsible for the strong growth is still open to question.

Thus, the relationship between trade policy and economic performance is a complicated issue that cannot be inferred from a simple correlation alone. As Morris and Adelman (1989, p. 1420) conclude, "success along this inward-oriented growth path varied greatly [in the late nineteenth century] . . . in moderately backward, import-substituting countries protection levels varied greatly and did not systematically accelerate economic growth . . . In sum, the effects of tariff policies are complex and vary greatly across countries in ways depending strongly on resources, institutions, and government strategies."

\section{What Explains the High Tariffs?}

Why did export-oriented countries such as Argentina levy high tariffs if they did not

5 The tariffs are commonly believed to have given certain manufacturers significant market power, to the possible detriment of other manufacturing industries. Gregory (1994, pp. 60-61) states that "there is no evidence of discretionary tariffs to favor specific industries or to encourage foreign industries to locate behind Russian tariff walls. Manufacturing inputs were taxed at the same rates as manufacturers." 
employ them as part of an import substitution trade strategy? In many cases, import duties were primarily designed to raise fiscal revenue for the government. Figure 3 illustrates that laborscarce, land-abundant countries often relied on customs duties to generate a large proportion of their government revenue. Figure 4 shows that these countries also tended to impose high tariffs.

Land abundant countries tended to impose high tariffs for public finance and for political economy reasons. In terms of public finance, import taxes made sense for countries with low population densities. Other means of raising revenue (excise taxes, land taxes, income taxes, etc.) were not as feasible or as enforceable in countries with a widely dispersed population, particularly in the late nineteenth century. The taxation of foreign goods arriving into the nation's ports reduced the problem of tax compliance. In terms of political economy, if a majority of the population owns land (or if the government is controlled by landowners), they may have an interest in avoiding direct taxes on land in favor of high taxes on imported luxury goods. $^{6}$

Revenue tariffs can be structured quite differently from protective tariffs and were not necessarily designed to protect domestic producers from foreign competition. Revenue tariffs are often levied on just a few key commodities (such as alcoholic beverages, coffee and tea, sugar

${ }^{6}$ As Platt (1972, p. 78) writes with respect to Argentina and other Latin American countries, "each of the Republics was feeling the pressure for more revenue, and for each, governed as it was by a landed oligarchy with a rooted distaste for direct taxation, the only obvious source of increased revenue was taxation on a larger import trade. . . A system of federal inland revenue was not developed in Argentina until as late as 1891, and in the mid-'90s the Customs House was accounting for between 70 and 80 percent of federal government revenues." As Solberg (1987, p. 106) notes,"the political base for a reorientation of Argentine economic policy toward protected industrialization did not exist [prior to World War I], for the pampa landed elite agreed with farmers as well as urban consumers that protectionism in an export-oriented economy would raise the cost of rural production and reduce aggregate real incomes." 
and tobacco), but are capable of raising more revenue than broadly based tariffs designed to protect domestic producers. In the case of Argentina, import duties on most capital goods and intermediate products related to the production and exports of staples entered duty free (such as machinery, iron and steel, chemicals, etc.), whereas imported consumption items (sugar, wine, etc.) were heavily taxed. The United Kingdom pursued a policy of free trade and did not use the tariff to discriminate in favor of domestic producers, but still levied import duties on noncompeting goods (such as sugar, tea, and coffee) and on other goods (tobacco manufactures) to balance domestic taxes on producers (Irwin 1993).

Thus, high tariff measures (customs revenue divided by imports) are an imperfect indicator of a country's trade-policy orientation and may not always reflect protectionist policies. Despite high measured tariffs, both Argentina and Canada ranked among the most open economies in the world in 1913, according to Estevadeordal's (1997) factor-endowment-based indicators of "openness" to trade.

\section{Conclusions}

This paper has questioned whether the correlation between tariffs and growth in the late nineteenth century by itself tells us anything about the relationship between trade policy and economic growth. Rapid growth in Argentina and Canada - two high tariff, high growth outliers - was based on an export-orientation in staple products, not industrialization based on import substitution. Labor-scarce and land-abundant countries such as Argentina and Canada often used import tariffs as a means of raising government revenue. But those attributes (as well as sound political institutions and other economic policies) also gave those countries unusually favorable 
prospects for economic growth. Rather than higher tariffs causing higher growth, the relationship could be spurious: land-abundant countries relied on customs duties to raise government revenue and also enjoyed favorable growth prospects, with little link between the two. 


\section{References}

Bairoch, Paul. "European Trade Policy, 1815-1914," in Peter Mathias and Sidney Pollard, eds., Cambridge Economic History of Europe, Vol. XIII. New York: Cambridge University Press, 1989.

Broadberry, Stephen N. "How Did the United States and Germany Overtake Britain? A Sectoral Analysis of Comparative Productivity Levels, 1870-1990." Journal of Economic History, June 1998, 58, pp. 375-407.

Cortés Conde, Roberto. "The Growth of the Argentine Republic, c. 1870 - 1914," in Leslie Bethell, ed., Argentina Since Independence. New York: Cambridge University Press, 1993.

Clemens, Michael A., and Jeffrey G. Williamson. “A Tariff-Growth Paradox? Protection's Impact the World Around, 1875-1997." National Bureau of Economic Research (Cambridge, MA) Working Paper No. 8459, September 2001.

Dohan, M. R. "Foreign Trade," in R. W. Davies, ed., From Tsarism to the New Economic Policy. Ithaca, NY: Cornell University Press, 1991.

Estevadeordal, Antoni. "Measuring Protection in the Early Twentieth Century." European Review of Economic History, April 1997, 1, pp. 89-126.

Gregory, Paul R. Before Command: An Economic History of Russia from Emancipation to the First Five-Year Plan. Princeton: Princeton University Press, 1994.

Haig, Bryan. "New Estimates of Australian GDP, 1861-1948/49." Australian Economic History

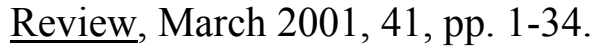

Irwin, Douglas A. "Free Trade and Protection in Nineteenth Century Britain and France Revisited: Comment on Nye," Journal of Economic History, March 1993, 53, pp. 146-152.

Irwin, Douglas A. "Tariffs and Growth in Late Nineteenth Century America." The World Economy, January 2001, 24, pp. 15-30.

Krueger, Anne O. “Trade Policy and Economic Development: How We Learn.” American Economic Review, March 1997, 87, pp. 1-22.

Maddison, Angus. The World Economy: A Millennial Perspective. Paris: OECD, 2001.

Morris, Cynthia Taft, and Irma Adelman. "Nineteenth Century Development Experience and Lessons for Today.” World Development, September 1989, 17, pp. 1417-1432.

O'Rourke, Kevin H. "Tariffs and Growth in the Late $19^{\text {th }}$ Century." Economic Journal, April 
2000, 110, pp. 456-483.

Platt, D. C. M. Latin America and British Trade 1806-1914. London: Adam \& Charles Black, 1972.

Reynolds, Lloyd. Economic Growth in the Third World, 1850-1980. New Haven: Yale University Press, 1985.

Solberg, Carl E. The Prairie and the Pampas: Agrarian Policy in Canada and Argentina, 18801930. Stanford: Stanford University Press, 1987.

Urquhart, M. C. "New Estimates of Gross National Product, Canada, 1870-1926: Some Implications for Canadian Development," in Stanley L. Engerman and Robert E. Gallman, eds., Long-Term Factors in American Economic Growth. Chicago: University of Chicago Press, 1986.

Urquhart, M. C. Gross National Product, Canada, 1870-1926: The Derivation of the Estimates. Montreal: McGill-Queen's University Press, 1993. 
$-13-$

Figure 1: Tariffs and Growth, 1870-1913: Core Countries

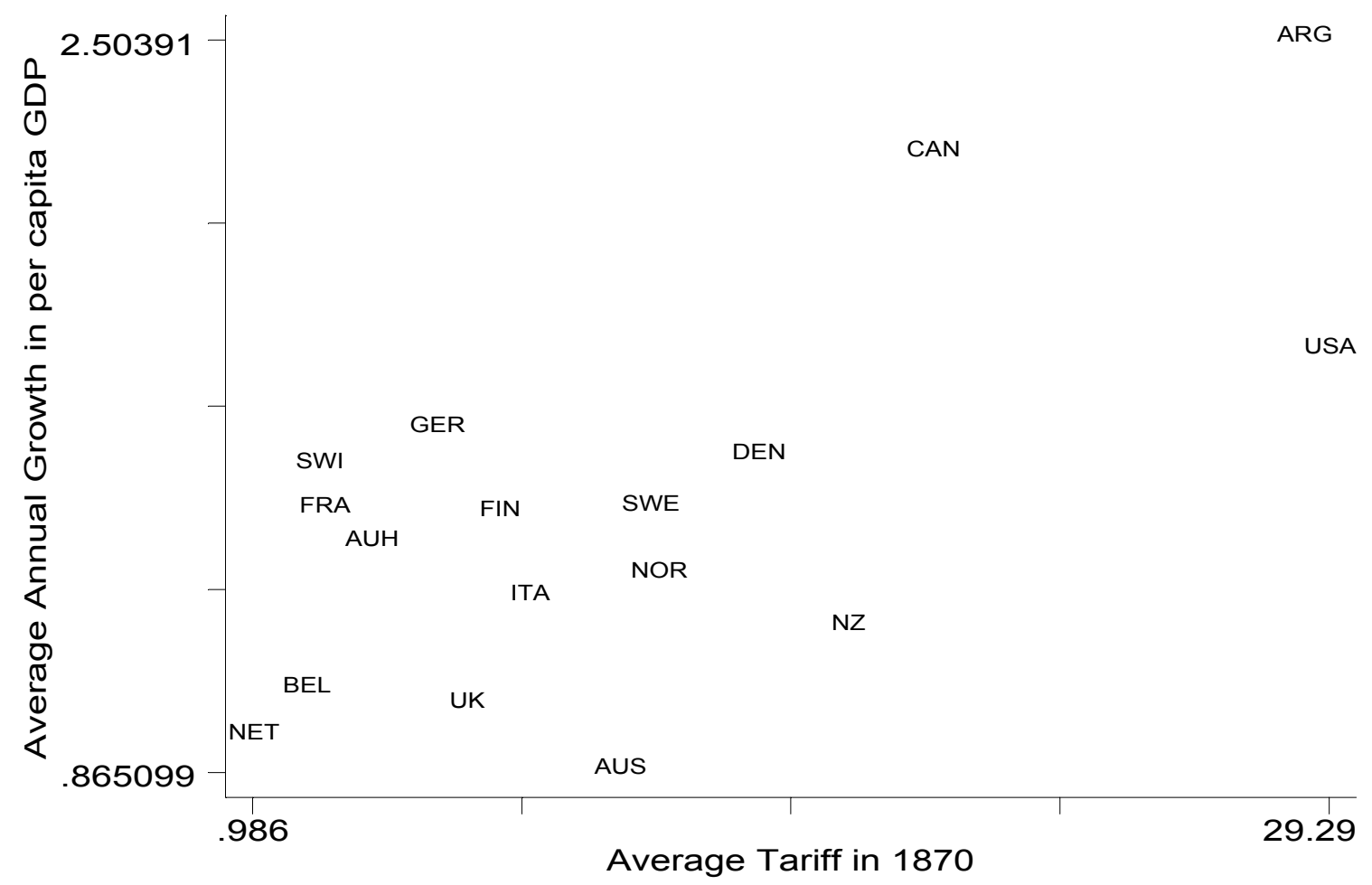


$-14-$

Figure 2: Tariffs and Growth, 1870-1913: Core and Periphery Countries

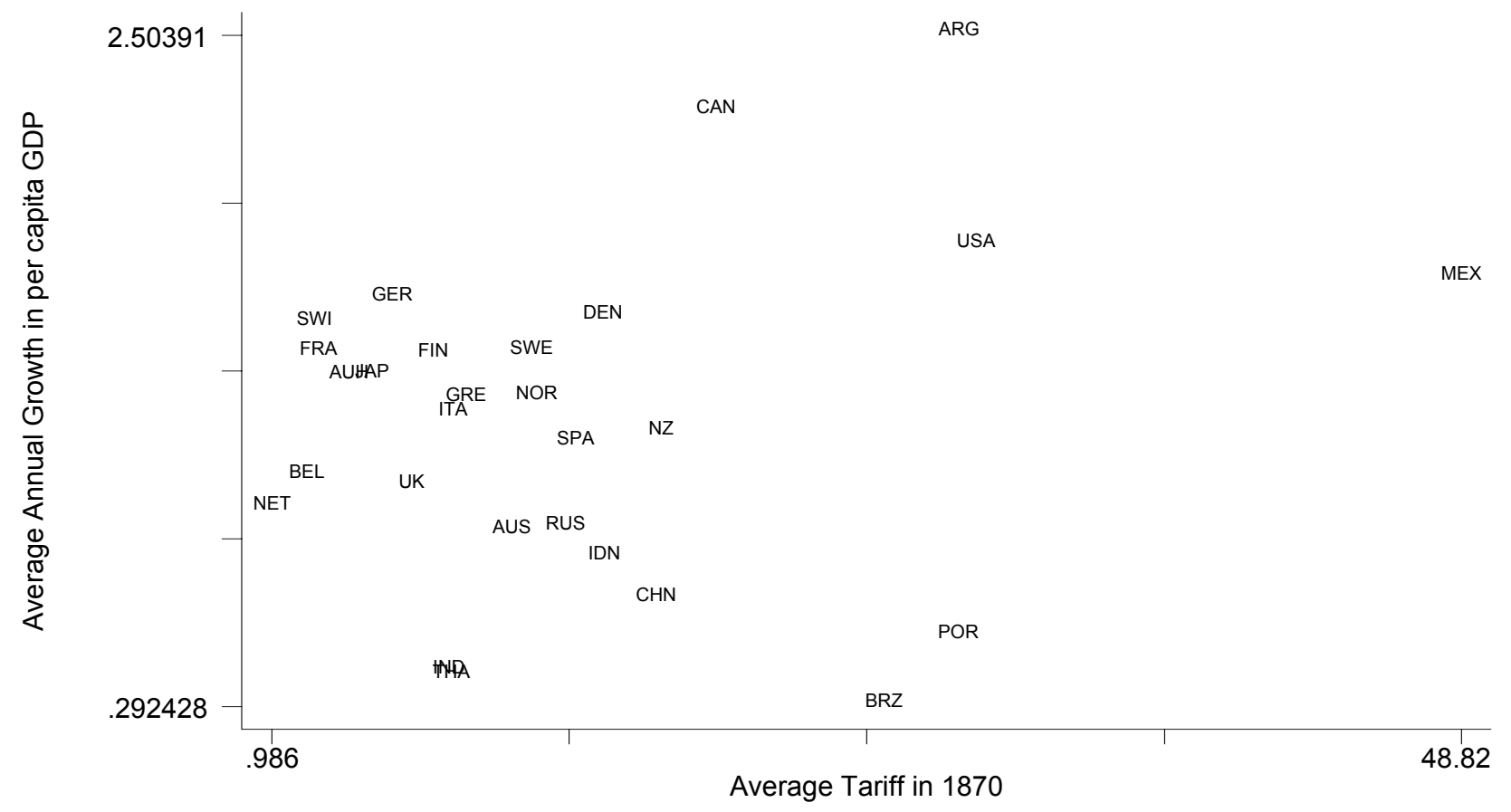


Figure 3: The Fiscal Importance of Customs Duties in 1890

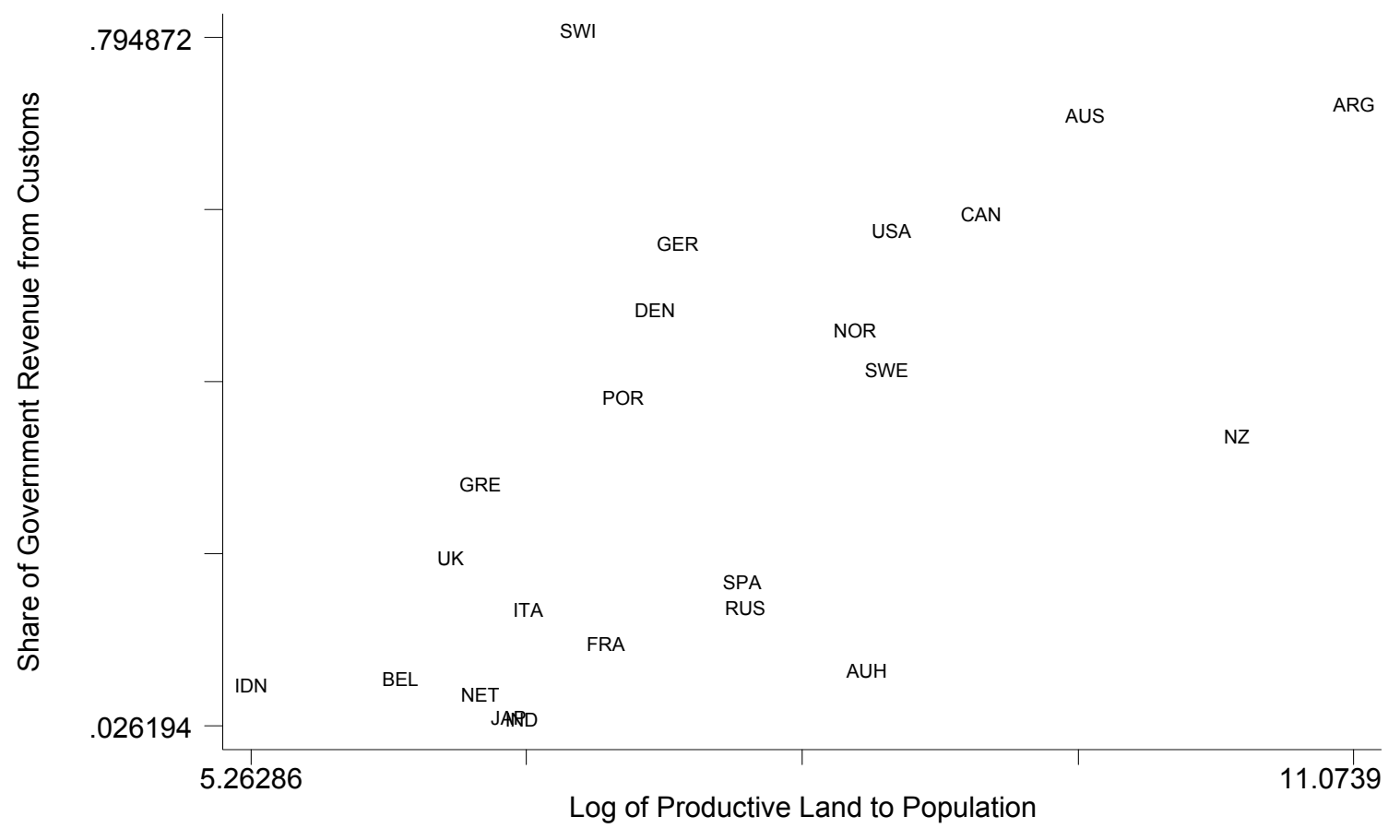


$-16-$

Figure 4: Average Tariffs and Relative Land Abundance in 1890

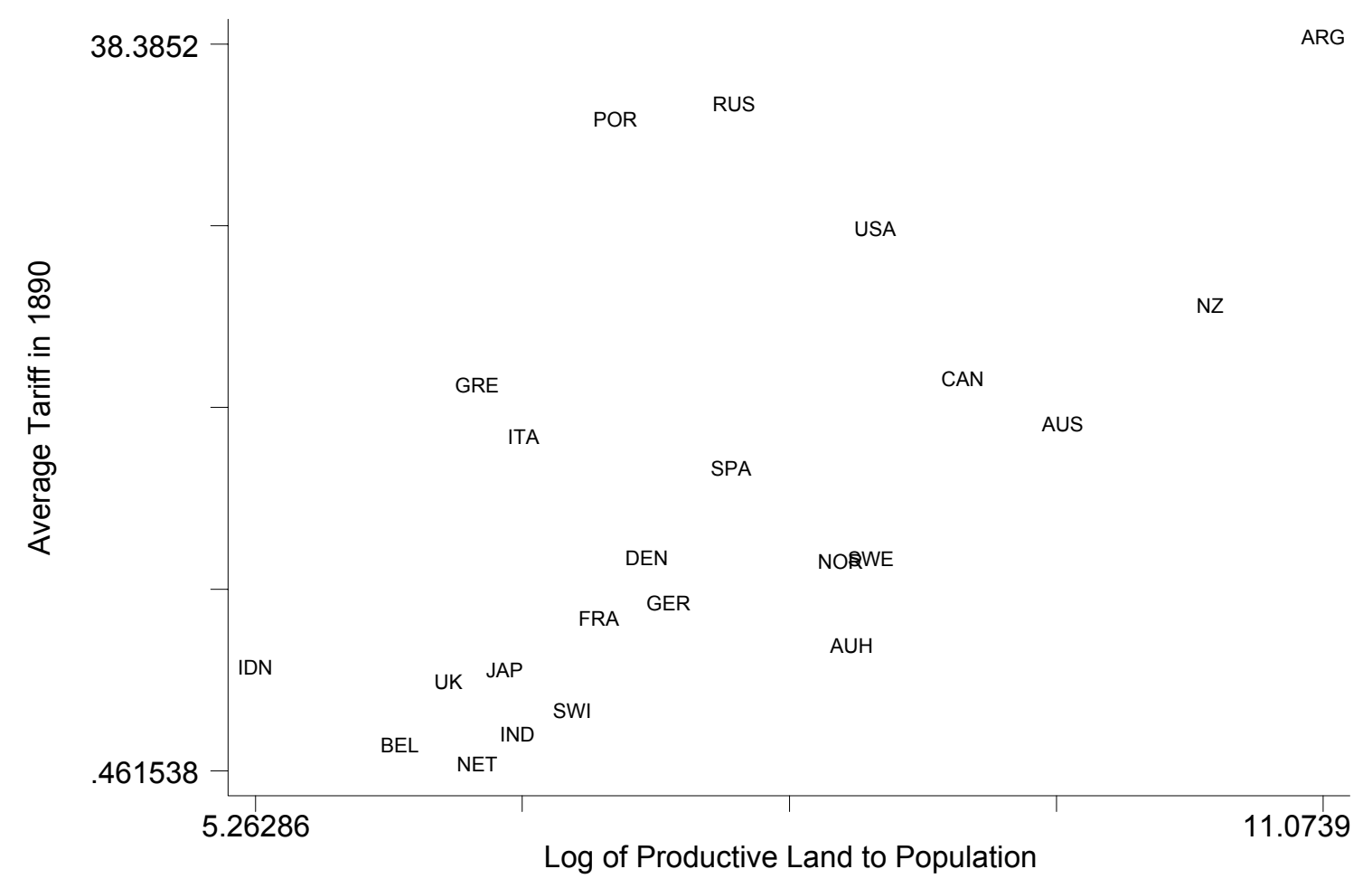

